\title{
Large Chicory aphid (Uroleucon cichorii (Koch, 1855): Sterrnorhyncha: Aphididae) - Invasive Alien Aphid Species in the Fauna of Belarus
}

\author{
Dmitriy Zhorov, Nadzeya Lyashchynskaya
}

Belarusian State University, Minsk, Republic of Belarus, Correspondence: zhorovdg@gmail.com

\begin{abstract}
Uroleucon cichorii (Insecta: Hemipteroidea: Rhynchota: Sternorrhyncha: Aphididae) is an invasive alien species in the fauna of Belarus. In 1854 the species has been described by C. L. Koch from Germany. For the first time U. cichorii has been noted in Great Britain in 1876, in Estonia - 1894, in Romania - 1896, in Italy - 1900, in Belgium - 1901, in Crimea - 1903, in Latvia - 1924, in Poland -1930, in Netherlands - 1939, in Finland 1941, in Ukraine - 1945, in France - 1948, in Sweden - 1949, in Norway - 1953, in Denmark - 1954, in Moldavia - 1955, in Austria - 1956, in Czech - 1958, in Hungary - 1959, in Bulgaria - 1960, in European Russia - 1962-1964, in Bosnia and Herzegovina - 1963, in Serbia - 1963, in Lithuania - 1963-1980, in Macedonia - 1964, in Switzerland - 1967, in Spain - 1971, in Sicily -1973, in Corsica - 1973, in Balearic Islands (Mallorca) - 1982, in Belarus - 1986 and Greece - after 1992.

It is obvious that this chronological list describes a history of aphidological research rather than spreading of the invider across the European regions. As considered, the species has Mediterranean origin. Outside of Europe the species is known from Near East as well as Central Asia, Korea and North America. As host plants $U$. cichorii s.str. uses common chicory (Cichorium intibus L.) and related species of Cichorieae (Asteraceae). The species is known as a pest of common chicory (including leaf chicory) and endive.

For the first time $U$. cichorii has been registered in 1986. At present the species is common for $C$. intibus growing on roadsides and in other ruderal biotopes. During 1986-2018 U. cichorii has been registered in the all regions of the Republic of Belarus. The map of geographic points of registrations is given. It is obvious that the invider's expansion in the regions of Belarus is finished.

The species is holocyclic and monoecious. Feeding on forage plants contributes to the loss of a significant amount of plastic substances, which leads to their dehydration and slow growth, and, as a result, a slight deformation of the stem. U. cichorii does not initiate the deformation of leaf blades and the premature dying off of the inflorescences, and also does not lead to the formation of galls.

Perennial data show the appearance of fundatrices from overwintering eggs in the third decade of April - the first decade of May. Further a series of successive parthenogenetic generations and the growth of colonies occur. The winged females are recorded in July-August. The appearance of winged males and normal females occurs in September - the first decade of October. The eggs are deposited in the end of October. The largest peak in the number of $U$. cichorii registrations occurs in July-August.
\end{abstract}

Key words: Aphidoidea, geographic distribution, biological cycle, alien species, biological invasions.

\section{Велика цикорієва попелиця (Uroleucon cichorii (Koch, 1855): Sterrnorhyncha: Aphididae) - інвазивний чужорідний вид фауни Білорусі}

\section{Дмитро Жоров, Надія Ліщинська}

Білоруський державний університет, Мінськ, Республіка Білорусь Адреса для листування: zhorovdg@gmail.com

Отримано: 22.03.19; прийнято до друку: 20.04.19; опубліковано: 28.06.19 
Резюме. Проаналізовано результати афідологічних публікацій про перші реєстрації великої цикорієвої попелиці (Uroleucon cichorii (Koch)) в країнах Свропи. Вид за межами континенту відзначений у Передній і Центральній Азії, Кореї. У Білорусі $U$. cichorii $є$ чужорідним видом, який здійснив експансію із Середземномор'я після успішної натуралізації й становлення кормової рослини - цикорію звичайного (Cichorium intybus L.) - як фонового елементу рудеральної та сегетальної рослинності.

У результаті обробки багаторічних (1986-2018рр.) зборів на території всіх адміністративних областей Білорусі складено карту реєстрацій $U$. cichorii. Найбільшу кількість реєстрацій відзначено в липні-серпні, що опосередковано відображає сезонну динаміку популяційної чисельності. Велика цикорієва попелиця $є$ відкритоживучою меристемофільною нетератогенною формою, належить до гербобіонтної фітобіонтної екологічної групи попелиць, в умовах Білорусі - спеціалізований монофаг цикорію звичайного. Біологічний цикл - повний, нормальний однодомний. Шкодить цикорію як декоративній, лікарській i сільськогосподарській культурі.

Ключові слова: Aphidoidea, географічне поширення, біологічний цикл, чужорідні види, біологічні інвазії.

\section{Introduction}

The study of 'biological invasions' phenomenon is currently on the keen focus as one of the major global ecological problems [1,2]. The geographic expansion processes of transcontinental and transregional transport communications that have been observed in recent decades, the active implementation of introduction work with the aim of improving the urban environment create prerequisites for an increase in the intensity of invasive processes [3].

The herbivorous insects, in particular Hemipteroidea, alien to the recent fauna of Belarus, form a large group of economically significant pests of economically valuable plants [4]. For that reason they should be considered invasive. Among them are the specialized phytophagous which feed on the plants with the status of adventitious species in the flora of Belarus. These plant species include such representatives as common coffeine-free.

The genus Cichorium L., 1753 includes 10 herbaceous plants species, among them 2 cultivated species: Cichorium endivia L. and C. intybus, and 8 wild species - Cichorium alatum Hochst. \& Steud., Cichorium bottae Deflers, Cichorium callosum Pomel, Cichorium calvum Sch. Bip. \& Asch., Cichorium dubium E.H.L. Krause, Cichorium hybridum Halácsy, Cichorium pumilum Jacq. and Cichorium spinosum L. [5]. Representatives of the genus are widely distributed in moderately warm and subtropical regions of Eurasia and Africa, as well as in many other extratropical countries of the world, both as introducents and cultivated plants [6].

Common chicory $(C$. intybus) is a perennial herbaceous plant, very polymorphous, with erect, striated, branching stem, $30-180 \mathrm{~cm}$ tall. Chicory has a fusiform, fleshy, reaching a length of 1,5 $\mathrm{m}$ taproot. The basal leaves are stalkless, lance-like to linear, with margins that either have dentations or more pinnate with sharply defined indentations, usually forming a rosette. The stem leaves are alternate, smaller, and partly clasping the stem. They can be entire or toothed. The flowerheads are numerous, placed at the top of the stems, or in the axils of the stem-leaves, generally in clusters of two or five. Inflorescence is a capitulum, flowers with light blue ligulas (quite rarely white or pink). Chicory flowers from June until September. Fertile flowers produce a dry smooth brownish cypsela (achene like seed). Reproduction is by seeds and by parts of the roots (vegetative) $[6,7]$.

In the conditions of Belarus, $C$. intybus flowers on the 2 nd year after the planting. The flowering period is observed from June to July, and seed producing occurs in July-September [8]. When not cultivated, chicory is found as a ruderal plant in dry meadows, roadsides and railway tracks, where they form large thickets.

Chicory originated in the Mediterranean $[9,10]$. Currently, the species is widely distributed throughout Europe, East Asia, India, Southern and Northern Africa, North, Central and South America, Australia and New Zealand [11].

C. intybus is one of the cultivated plant species and is widely used as a medicinal, food (vegetable), fodder and melliferous culture [12]. Milky juice of chicory contains bitter substances, such as lactucin, lactucopicrin, etc., which have a positive effect on the increase in appetite. The roots of $C$. intybus are used to produce coffeine-free chicory coffee, as well as for making beverages that have an astringent and antimicrobial effect. The use of this kind of infusions increases and improves the appetite and functioning of the digestive system. Chicory is used in the treatment of diabetes. Syrup, derived from chicory root, is used in canning and confectionery production. Chicory is a good melliferous culture. Under favourable weather conditions, its median productivity can reach up to $100 \mathrm{~kg} / \mathrm{ha}$ [13].

Common chicory was introduced on the territory of Belarus in the 60s of the 20th century [14] as a medicinal plant, occasionally it is planted as a food crop for the production of coffee-like drinks. At present, $C$. intybus is ubiquitous, common in dry lands and lands with ruderal vegetation.

In the conditions of Belarus, chicory is damaged by a number of phytophagous insects. Leaf-miner 
flies of Agromyzidae family, Napamysa lateralis (Fall.) and Ophiomia pinguis (Fall.), damage the leaves and underground parts of the plant. On C. endivia roots were recorded the rhizobiont forms of Aphidoidea - dioecious gall-forming aphid species from family Eriosomatidae - Pemphigus bursarius L. Also chicory is damaged by another specialized invasive species feeding on herbs - large chicory aphid (Uroleucon cichorii (Koch)).

The purpose of this paper was to examine the current distribution of the large chicory aphid (Uroleucon cichorii (Koch)) throughout Europe and Belarus, in particular, as well as its bioecological characteristics in the context of the study region.

\section{Material and Methods}

The paper is based on the analysis of a vast number of bibliographic works containing information about the presumably first record of the large chicory aphid in different countries and regions in Europe. The data obtained are used to get an overview about the species distribution throughout the European continent. To assess the current dynamics of the species distribution in Belarus, perennial registrations and collections of entomological material were carried out by the authors in all 6 administrative regions, 5 landscapegeographical provinces [15], 7 forest vegetation [16] and 4 agroclimatic [17] zones, as well as 5 tree introduction districts [18] of Belarus. The collection of material was carried out according to generally accepted methods of aphidological studies [19].

\section{Results and Discussion}

The large chicory aphid was first described in Germany by K. L. Koch in 1854 as Siphonophora cichorii Koch. The analytical review of printed works of different years on $U$. cichorii makes it possible to state that the species has many synonymous names, which are shown in table 1 .

The introduction and widespread cultivation of C. intybus created the prerequisites for the expansion of $U$. cichorii beyond its natural, historically formed area, which is considered the territory of the Mediterranean. By the first decade of the current century, the species was recorded in Eastern, Northern, Central, Southern and Western Europe. Figure 1 shows years, table 1 shows as well as the publications with presumably first records of the chicory aphid for the Old World countries. The exceptions are Portugal, Slovenia, Croatia and Iceland (fig. 1), since the data about $U$. cichorii are not available in these countries. Outside Europe the species is recorded in the Near East and Central Asia, Eastern Siberia, and Korea [19].

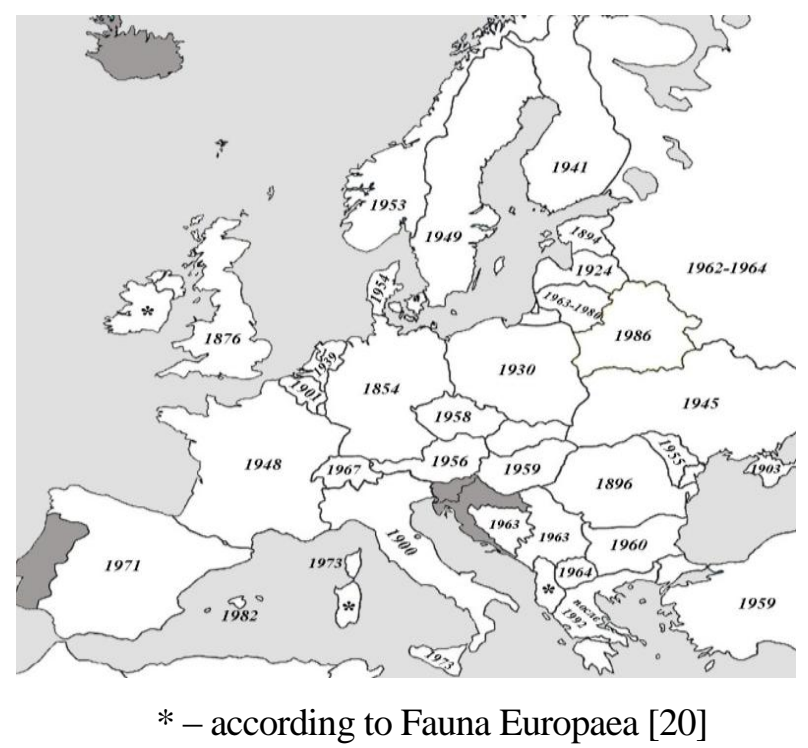

Fig. 1. Distribution of the Large Chicory Aphid (Uroleucon Cichorii (Koch, 1855)) Throughout Europe, by Years of Registration

Table 1

Chronology of Publications Which Content Information on Registrations of the Large Chicory Aphid (Uroleucon Cichorii (Koch, 1855)) in the European Regions

\begin{tabular}{|c|c|c|c|}
\hline $\begin{array}{l}\text { Years of the First } \\
\text { Registration }\end{array}$ & Regions & $\begin{array}{l}\text { Synonyms / } \\
\text { Host Plants }\end{array}$ & Literary Source \\
\hline 1 & 2 & $\mathbf{3}$ & 4 \\
\hline 1854 & Germany & $\begin{array}{c}\text { Siphonophora cichorii Koch / } \\
\text { Cichorium intybus L. }\end{array}$ & [21] \\
\hline 1876 & Great Britain & $\begin{array}{c}\text { Macrosiphum cichorii (Koch) / } \\
\text { Agrostemma githago L., Cichorium intybus L. }\end{array}$ & [22] \\
\hline 1894 & Estonia & $\begin{array}{c}\text { Siphonophora serratulae Koch / } \\
\text { Cirsium sp. }\end{array}$ & [23] \\
\hline 1896 & Romania & $\begin{array}{c}\text { Siphonophora picridis } \mathrm{F} . / \\
\text { Cichorium intybus L. }\end{array}$ & [24] \\
\hline 1900 & Italy & $\begin{array}{l}\text { Siphonophora pricridis / } \\
\text { Picridium vulgare Desf. }\end{array}$ & [25] \\
\hline 1901 & Belgium & $\begin{array}{l}\text { Macrosiphum cichorii Koch / } \\
\text { Cichorium } \mathrm{sp.}\end{array}$ & [26] \\
\hline
\end{tabular}


Велика цикорієва попелиия (Uroleucon cichorii (Koch, 1855): Sterrnorhyncha: Aphididae) - інвазивний чужсорідний вид фауни Білорусі

\begin{tabular}{|c|c|c|c|}
\hline 1 & 2 & 3 & 4 \\
\hline 1903 & Crimea & $\begin{array}{c}\text { Siphonophora cichorii Kalt. / } \\
\text { Centaurea } \mathrm{sp} .\end{array}$ & [27] \\
\hline 1924 & Latvia & $\begin{array}{l}\text { Macrosiphum pirdicis Fabr., } 1794 \text { / } \\
\text { Leontodon autumnalis L. }\end{array}$ & {$[28]$} \\
\hline 1930 & Poland & $\begin{array}{l}\text { Macrosiphum picridis Fabr. / } \\
\text { Cichorium intybus L. }\end{array}$ & [29] \\
\hline 1939 & Netherlands & $\begin{array}{l}\text { Dactynotus cichorii Koch / } \\
\text { Cichorium intybus L. }\end{array}$ & [30] \\
\hline 1941 & Finland & $\begin{array}{l}\text { Dactynotus cichorii }(\text { Koch }) / \\
\text { Lapsana communis L. } \\
\end{array}$ & [31] \\
\hline \multirow{2}{*}{1945} & \multirow{2}{*}{ Ukraine } & $\begin{array}{l}\text { Dactynotus cichorii Koch / } \\
\text { Cichorium intybus L. }\end{array}$ & [32] \\
\hline & & $\begin{array}{l}\text { Megalosiphum picridis } \text { Fabr. / } \\
\text { Cichorium intybus } \mathrm{L} .\end{array}$ & [33] \\
\hline 1948 & France & $\begin{array}{l}\text { Dactynotus cichorii Koch / } \\
\text { Cichorium sp. }\end{array}$ & [34] \\
\hline 1949 & Sweden & $\begin{array}{l}\text { Dactynotus cichorii }(\text { Koch }) / \\
\text { Lapsana communis L. }\end{array}$ & [35] \\
\hline 1953 & Norway & $\begin{array}{c}\text { Dactynotus cichorii }(\text { Koch) / } \\
\text { Leontodon autumnalis } \mathrm{L} . \\
\end{array}$ & [36] \\
\hline 1954 & Denmark & $\begin{array}{c}\text { Dactynotus cichorii (Koch, 1855) / } \\
\text { Cichorium intybus L. }\end{array}$ & [37] \\
\hline 1955 & Moldavia & $\begin{array}{c}\text { Dactynotus cichorii Koch / } \\
\text { Cichorium intybus L. }\end{array}$ & [38] \\
\hline 1956 & Austria & $\begin{array}{l}\text { Dactynotus cichorii }(\text { Koch }) / \\
\text { Cichorium intybus L. }\end{array}$ & [39] \\
\hline 1958 & Czech & $\begin{array}{l}\text { Uroleucon cichorii (Koch, 1955) / } \\
\text { Cichorium endivia L. }\end{array}$ & [40] \\
\hline 1959 & Hungary & $\begin{array}{c}\text { Dactynotus cichorii Koch / } \\
\text { Cichorium intybus L. }\end{array}$ & [41] \\
\hline 1960 & Bulgaria & $\begin{array}{c}\text { Dactynotus (Dactynotus) cichorii (Koch) / } \\
\text { Cichorium intybus L. }\end{array}$ & {$[42]$} \\
\hline 1962-1964 & European Russia & $\begin{array}{c}\text { Dactynotus cichorii }(\mathrm{Koch}) / \\
\text { Cichorium intybus } \mathrm{L} .\end{array}$ & {$[43,44]$} \\
\hline 1963 & $\begin{array}{l}\text { Bosnia and } \\
\text { Herzegovina }\end{array}$ & $\begin{array}{l}\text { Uroleucon cichorii (Koch, 1955) / } \\
\text { Cichorium intybus L. }\end{array}$ & {$[45]$} \\
\hline 1963 & Serbia & $\begin{array}{l}\text { Uroleucon cichorii (Koch, 1855) / } \\
\text { Cichorium intybus } \mathrm{L} .\end{array}$ & [45] \\
\hline 1963-1980 & Lithuania & $\begin{array}{c}\text { Uroleucon cichorii (Koch, 1855)/ } \\
\text { Cichorium intybus L. }\end{array}$ & {$[46]$} \\
\hline 1964 & Macedonia & $\begin{array}{l}\text { Uroleucon cichorii (Koch, 1855)/ } \\
\text { Cichorium intybus } \mathrm{L} .\end{array}$ & [45] \\
\hline 1967 & Switzerland & $\begin{array}{c}\text { Uroleucon cichorii (Koch, 1855) / } \\
\text { Senecio paludosus L. }\end{array}$ & [47] \\
\hline 1971 & Spain & $\begin{array}{c}\text { Uroleucon (Uroleucon) cichorii (Koch, 1955) / } \\
\text { Crepis taraxacifolia (Thull.) }\end{array}$ & [48] \\
\hline 1973 & Sicily & $\begin{array}{c}\text { Uroleucon cichorii (Koch, 1855) / } \\
\text { Cichorium intybus L. }\end{array}$ & [49] \\
\hline 1973 & Corsica & $\begin{array}{l}\text { Uroleucon cichorii }(\mathrm{Koch}) / \\
\text { Cichorium intybus } \mathrm{L} .\end{array}$ & {$[50]$} \\
\hline 1982 & $\begin{array}{l}\text { Balearic Islands } \\
\text { (Mallorca) }\end{array}$ & $\begin{array}{l}\text { Uroleucon (Uroleucon) cichorii (Koch, 1955) / } \\
\text { Cichorium intybus L., Crepis tectorum subsp. } \\
\text { tectorum, Reichardia picroides (L.) Roth }\end{array}$ & [51] \\
\hline 1986 & Belarus & $\begin{array}{c}\text { Uroleucon cichorii cichorii (Koch, 1855) / } \\
\text { Cichorium intybus L. }\end{array}$ & [52] \\
\hline after 1992 & Greece & $\begin{array}{c}\text { Uroleucon (Uroleucon) cichorii (Koch) / } \\
\text { Cichorium sp. }\end{array}$ & [53] \\
\hline
\end{tabular}


As indicated in table 1, for Belarus U. cichorii was first collected by prof. S. V. Buga (1986) namely in Priluki Village, Minsk District, Minsk Region, on Cichorium intybus L. [52]. Registration points of the large chicory aphid during the field seasons 19862018 in accordance with the information of the database «Aphids of Belarus» [54] are displayed on the map (fig. 2).

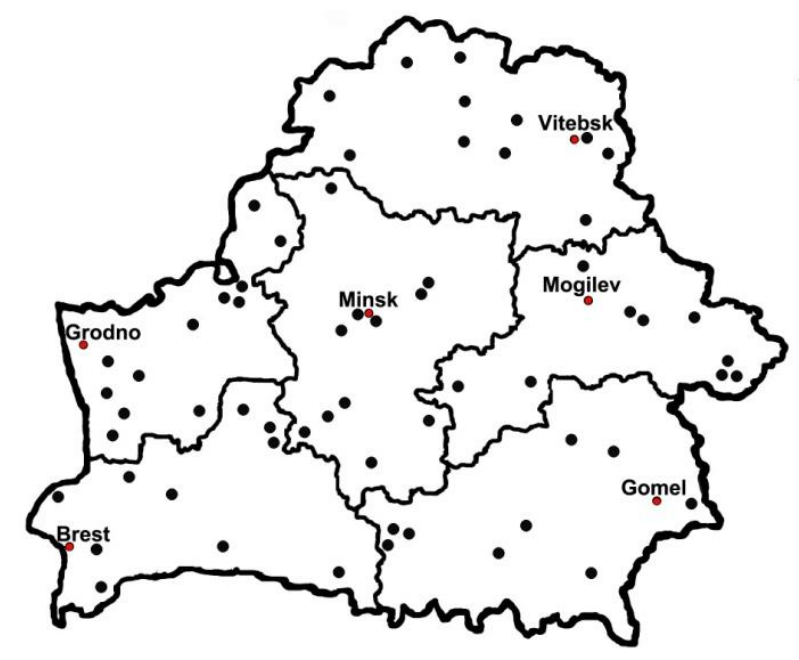

Fig. 2. The Large Chicory Aphid (Uroleucon Cichorii (Koch, 1855)) Registration Points in Belarus During 1986-2018

The registration data of the large chicory aphid in Belarus (fig. 2) demonstrate that by now the area of distribution of the species covers the territories of all administrative regions, physiographic provinces, forest vegetation and agroclimatic zones, as well as the introduction and dendrological regions of Belarus. The spesies penetrated into the adventive complex of aphids associated with herbaceous plants in Belarus.

The trophic specialization of the large chicory aphid is characterized by the nutrition and development exclusively on herbaceous plants, which determines its belonging to a herbivorous phytobiont ecological group. The imago and larvae of $U$. cichorii are localized on the upper parts of the stems and inflorescences of the chicory. They form loose aggregations, which makes it possible to rank them among the open-living species feeding on meristem. $U$. cichorii uses common chicory and related species Cichorieae as the host plants (Crepis, Hieracium, Lactuca, Lapsana, Leontodon, etc.). In the Palaearctic region the large chicory aphid is recorded on the whole spectrum of food plants, which are represented by families Asteraceae: Aetheorhiza: Aetheorhiza bulbosa (L.) Cass.; Andryala: Andryala integrifolia L., A. ragusina L., Aster maackii (?); Chondrilla: Chondrilla integrifolia
L., Cichorium: Cichorium endivia L., C. intybus L.; Cirsium: Cirsium vulgare (Savi) Airy-Shaw.; Crepis: Crepis alpestris (Jacq.) Tausch, C. biennis L., C. blattarioides Vill., C. capillaris (L.) Wallr., C. conyzifolia (Gouan) A. Kerner, C. foetida L., C. grandiflora L., C. hieracioides Waldst. \& Kit., C. nicaeensis Balbis, C. paludosa (L.) Moench, C. praemorsa (L.) Tausch., C. rhoeadifolia Bieb., C. setosa F. Haller, C. sibirica L., C. tectorum L., C. vesicaria L., C. vesicaria haenseleri (Boiss. ex DC.) P.D. Sell, C. virens = C. capillaris; Hedypnois: Hedypnois cretica (L.) Dum.-Cours., Hedypnois polymorpha $=$ H. cretica; Helichrysum spp.; Hieracium: Hieracium aurantiacum L., Hieracium auricula Auct., non L. $=$ H. lactucella, $H$. brachiatum Bertol. ex Lam., H. dubium L., H. lactucella Wallr., $H$. murorum L. AGG., $H$. pilosella L., H. piloselloides Vill., H. umbellatum L.; Hyoseris: Hyoseris radiata L.; Hypochoeris: Hypochoeris achyrophorus L., H. maculata L., $H$. radicata L., H. ramose; Lactuca: Lactuca perennis L., L. sativa L., L. serriola (L.) Torn, L. viminea chondrilliflora (Boreau) Bonnier; Lapsana: Lapsana communis L.; Leontodon: Leontodon autumnalis L., L. crispus Vill., L. danubialis Jacg., L. hispidus L., L. hispidus alpinus (Jacq.) Finch \& P. D. Sell, L. hispidus danubialis (Jacq.) Simonkai; Picris: Picris hieracioides L.; Reichardia: Reichardia picroides (L.) Roth; Senecio: Senecio erucifolius (?), Seriola aetnensis = Hypochoeris achyrophorus; Sonchus: Sonchus arvensis L., S. asper (L.) Hill, S. oleraceus L., Taraxacum: Taraxacum officinale Weber; Tragopogon spp.: Resedaceae: Reseda: Reseda luteola L.; Polygonaceae: Rumex spp.; Campanulaceae: Campanula spp. [55]. The broad spectrum of forage plants indicates that in most countries of Europe U. cichorii belongs to seconddegree oligophagous. In Belarus the large chicory aphid belongs to a number of specialized monophagous [4].

Feeding on forage plants contributes to the loss of a significant amount of plastic substances, which leads to their dehydration and slow growth, and as a result, a slight deformation of the stem. $U$. cichorii does not initiate the deformation of leaf blades and the premature dying off of the inflorescences, and also does not lead to the formation of galls. That's why it refers to nonteratogenic forms.

Under the conditions of Belarus [4], as well as in the neighboring countries of Europe [56-58], the large chicory aphid is holocyclic and monoecious. The morphs are represented by fundatrices, larvae, nymphs, virginoparae and sexuparae (males and oviparae). The whole cycle of aphid development takes place on the main host plant - chicory. 
Велика цикорієва попелищя (Uroleucon cichorii (Koch, 1855): Sterrnorhyncha: Aphididae) - інвазивний чужсорідний вид фауни Білорусі

Perennial data show the appearance of fundatrices from overwintering eggs in the third decade of April - the first decade of May. Further occurs a series of successive parthenogenetic generations and the growth of colonies. The winged females are recorded in July-August. The appearance of winged males and normal females occurs in September - the first decade of October. The eggs are deposited in the end of October. The largest peak in the number of $U$. cichorii registrations occurs in July-August (fig. 3).

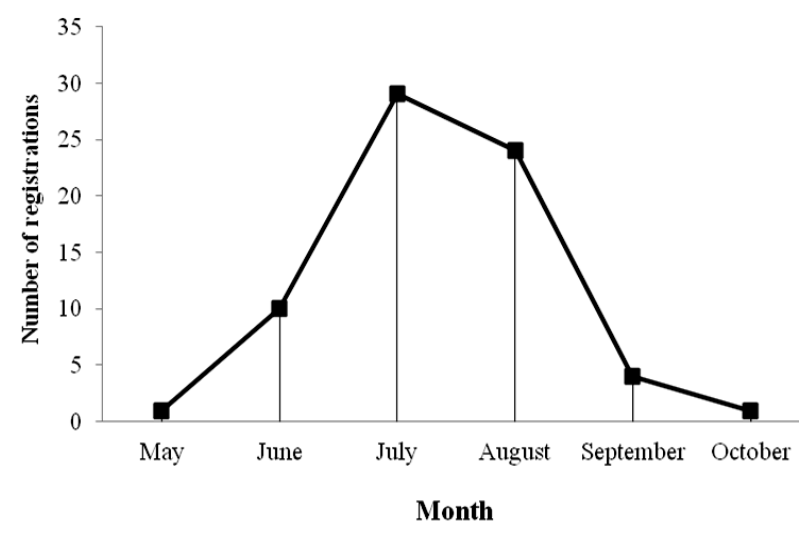

Fig. 3. Seasonal Abundance of the Large Chicory Aphid (Uroleucon Cichorii (Koch, 1855)) in Belarus Based on Perennial Field Data (1986-2018)

\section{Conclusion}

The results obtained show that the large chicory aphid (U. cichorii) is widespread throughout Europe. In Belarus, the species has completed expansion the country and penetrated into the adventive complex of aphids associated with herbaceous plants. The analysis of the bioecological characteristics of $U$. cichorii in Europe and Belarus makes it possible to classify it as an open-living, non-teratogenic species feeding on meristems. The species belongs to the herbivorous phytobiont ecological group. According to the trophic specialization, in Belarus U. cichorii belongs, - to specialized monophagous. The biological cycle is holocyclic and monoecious in Europe and Belarus both. In the conditions of Belarus the peak of $U$. cichorii registrations occurs in JulyAugust.

\section{References}

1. Convention on Biological Diversity (CBD): Montreal, Canada, 2019. [Online]; URL: https://www. cbd.int/convention/ (accessed April 16, 2019).

2. Handbook of Alien Species in Europe: Drake J. A., Ed.; Springer: Netherlands; 2009.
3. Roques, A. Taxonomy, time and geographic patterns. BioRisk; 2010, 4, pp 11-26.

4. Жоров, Д. Г. Инвазивные виды гемиптероидных насекомых (Insecta: Hemipteroidea) Беларуси (таксономический состав, экологические группы, географическое распространение, биологические основы вредоносности). Автореферат дис. канд. биол. наук. Минск, 2017; 25 с.

5. The Plant List: Royal Botanic Gardens, Kew \& Missouri Botanical Garden, version 1.1, 2013. [Online]; URL: http://www.theplantlist.org/ (accessed April 6, 2019).

6. Флора СССР: Комаров В. Л., Ред.; Т. 29: Подсемейство Цикориевых (Cichorioideae): Комаров В. Л.; Бобров Е. Г.; Цвелев Н. Н., Ред.; Наука: Москва, Ленинград; 1964.

7. Дудченко, Л. Г.; Козьяков, А. С.; Кривенко, В. В. Пряно-ароматические и пряновкусовые растения; Наукова думка: Киев; 1989.

8. Информаиионнопоисковая система Центрального ботанического сада Наџиональной академии наук Беларуси, 2019. [Online]; URL: http://hbc.basnet.by/hbcinfo/ (Дата обращения Апрель 16, 2019).

9. Флора БССР. Шишкин Б. К. Томин М. П. Ред.; 1945-1959: Т. 5: Compositae: Шишкин Б. К., Томин М. П., Ред.; Изд-во Академии наук Белорусской ССР: Минск; 1959.

10. Растительные ресурсы СССР: Цветковые растения, их химический состав, использование. Семейство Asteraceae (Compositae): Соколов П. Д., Ред.; Наука: Санкт-Петербург; 1993.

11. Ареалы лекарственных и родственных им растений СССР: Шмидт В. М., Ред.; Изд-во Ленинград ун-та: Ленинград; 1990.

12. Кухарева, Л. В.; Пашина, Г. В. Полезные травянистые растения природной флоры: справочник по итогам интродукиии в Белоруссии; Наука и техника: Минск; 1986; с 46.

13. Абрикосов, Х. П.; Александрова, Л. В.; Алексеенко, Ф. М.; Бакулева, Н. А.; Глухое, М. М.; Глушков, И. М.; Гребельский, С. Г. и др. Цикорий. В Словаре-справочнике пчеловода; Сельхозгиз: Москва; 1955; с 395.

14. Древесные растения Центрального ботанического сада АН БССР: Нестерович Н. Д., Ред.; Наука и техника;,Минск; 1982.

15. Марцинкевич, Г. И.; Клицунова, Н. К.; Счастная, И. И.; Якушко, О. Ф. Теоретические проблемы и результаты комплексного географиического районирования территории Беларуси. Выбранныя навуковыя працы БДУ; 2001, 7, с 333-356.

16. Юркевич, И. Д.; Голод, Д. С.; Адерихо, В. С. Растительность Белоруссии, ее картографирование, охрана и использование; Наука и техника: Минск; 1979.

17. Мельник, В. И. Влияние изменения климата на агроклиматические ресурсы и продуктивность основныхх сельскохозяйственных культур Беларуси. Автореферат дис. канд. геогр. наук. Минск, 2004; 21 с.

18. Нестерович, Н. Д. Интродукционные районы и древесные растения для зеленого строительства в Белорусской ССР; Наука и техника: Минск; 1982. 
19. Aphids on the world's plants: An online identification and information guide: Blackman R., Ed.: London: Natural History Museum, 2012. [Online]; URL: http://www.aphidsonworldsplants.info (accessed April 16, 2019).

20. Fauna Europaea: Museum für Naturkunde Leibniz-Institut für Evolutions - und Biodiversitätsforschung, version 2.6, 2013. [Online]; URL: http://www.fauna-eu.org/ (accessed April 16, 2019).

21. Koch, C. L. Die pflanzenlause Aphiden: getreu nach dem Leben abgebildet und beschrieben: J. L. Lotzbeck: Nurnberg, 1854; p 184.

22. Davidson, J. A list of British Aphides (Including Notes on Their Synonymy, Their Recorded Distribution and Food Plants in Britain, and a Food-plant Index): Green: Longmans, 1925; p 21.

23. Холодковский, Н. А. II. Объяснительная каталогъ коллекиіи тлей (Aphidae): СанктПетербург, 1898; с 1-24.

24. Henrich, C. Verzeichnis der in der naheren Umgebung von Herrmannstadt beobachteten Aphiden. Verh. Mitt. Sieb. Ver. Naturw; 1896, 45, pp 23-31.

25. Del Guercio, G. Prostetto Dell'Aphidofauna Italica. Nuove Relizioni Regia Stazione di Entomologia Agraria di Firenze; 1900, 2, p 169.

26. Schouteden, M. N. Le genere Siphonophora C. Koch. Annales de la societe entomologique de Belgique; 1901, 45, pp 111-117.

27. Cholodkovsky, N. Zur Kenntnis der Aphiden der Krim (Homoptera Aphididae). Revue Russe d'Entom; 1910, 10 (1), pp 144-149.

28. Opmanis, K. Ein beitrag zur Kenntnis der Aphidenfauna Lettlands; Riga, 1928, pp 16-17.

29. Judenko, E. Materjaly do fauny mszyc (Aphididae) ocolicy Pulaw z uwzglednieniem biologji. 2. Polskiego pisma entomologicznego; 1931, 10 (2), pp 102-118.

30. Hille Ris Lambers, D. Contributions to a monograph of the Aphididae of Europe. II. The genera Dactynotus Rafinesque; 1818; Staticobium Mordvilko, 1914; Macrosiphum Passerini, 1860; Masonaphisnov. gen.; Pharalis Leach, 1826. Temminckia 1939, 4, p 16.

31. Heikinheimo, O. Fur die finnische Fauna neue Blattlause (Hom., Aphidoidea). Suomen Hyonteistieteellinen Aikakauskirja (Annales Entomologici Fennici); 1944, 10 (1), pp 1-7.

32. Божко, М. П. Фауна тлей (Aphididae) луговой Михайловской степи, Сумской области. Tруды научно-исследовательского института биологии Харьковского государственного университета им. А. М. Горького; 1953, 18, pp 163-169.

33. Мамонтова, В. О. Попелиці (Aphidoidea) Канівського біогеографічного заповідника. Tpуды Канівського біогеографічного заповідника; 1949, 7, pp 87-116.

34. Remaudiere, G. Contribution a l'etude des Aphidoidea de la faune Francaise. Aphididae: Dactynotinae et Myzinae (a). Revue de Pathologie vegetale et D'Entomologir agricole de France; 1951, 30 (2), pp 125-144.

35. Ossiannilsson, F. Contributions to the Knowledge of Swedish Aphids. II. List of Species with
Find Records and Ecological Notes. The Annals of the royal agricultural college of Sweden; 1959, 25, pp 375527.

36. Tambs-Lyche, H. Studies on Norwegian Aphids (Hom., Aphidoidea) I. The subfamily Dactynotinae Börner. Norsk entomologisk Tidsskrift; 1968, 15 (1), pp 1-17.

37. Heie, O. A list of Danish Aphids. 1.: Macrosiphoniella Del Guerc. and Dactynotus Raf. Entomologike Meddelelser; 1960, 29, pp 193-211.

38. Божко, М. П. Материалы к познанию фауны тлей (Aphidoidea) правобережной Украины и Молдавии. Труды института биологии и биологического факультета Харьковского ордена трудового красного знамени государственного университета им А. М. Горького; 1957, 30; pр 223-240.

39. Franz, H. Zur Kenntnis der Aphidenfauna Kärntens. Mitt. Natur. Heimat. Kämt; 1959, 69, pp 84-94.

40. Holman, J. Aphis (Homoptera, Aphidoidea) and their host plants in the Botanical Garden of Charles University in Prague. Acta Univ. Carolinae Biologica; 1991, 35, pp 19-55.

41. Pintera, A.; Szalay-Marzso, L. Neuere angaben zur kenntnis der Blattlaus (Aphidoidea) fauna Ungarns. Acta Zoologica Academiae Scientiarum Hungaricae; 1962, 8 (1-2), pp 127-133.

42. Ташев, Д. Г. Нови листни въшки (Hom., Aphid.) за фауната на България. Annuaire de l'universite de Sofia; 1958/1959, 53, pp 157-162.

43. Шапошников, Г. Х. Подотряд Aphidinea Тли. Определитель насекомых европейской части СССР: Т. 1: Низшие, древнекрылые, с неполнымм превращением: Бей-Биенко Г. Я., Ред.; Наука: Москва, Ленинград; 1964; с 489-616.

44. Носырев, В. И. К изучению тлей на лекарственных фармакопейных растениях в условиях Московской области. В Говорят молодые ученые, доклады на первой Московской областной конференции молодых ученых: Москва, 1966; с 203-207.

45. Eastop, V. F.; Tanasijevic, N. Aphid records from Yugoslavia. Entomologist's monthly magazine; 1968, 104, pp 55-57.

46. Rupais, A. A.; Juronis, V. Aphides found in Kaunas and its environs in 1963-1980. Liet Tsr Aukst Mokyklu Mokslo Darb (C); 1983, 3, pp 57-65.

47. Lampel, G.; Meier, W. Hemiptera: Sternorrhyncha - Aphidina. 2: Aphididae. Fauna Helvetica; 2007, 16, p 415.

48. Nieto Nafria, J. M. Aphidinea de la cordillera central y provincial de Salamanca; Madrid, 1974; p 115.

49. Barbagallo, S.; Stroyan, H. L. G. Osservazioni biologiche, ecologiche e tassinomiche sull'aphidofauna della Sicilia. Frustula Entomologica; 1982, 3 (16), pp 1-182.

50. Stary, P.; Leclant, F.; Lyon, J. P. Aphidiides (Hym.) et Aphides (Hom.) de Corse. I. Les Aphidiides. Annales de la Societe entomologique de France; 1975, 11 (4), pp 745-762.

51. Seco, M. V.; Mier, M. P. Contribuciones al conocimiento de los pulgones (Hom. Aphidoidea) de las Islas Baleares. I. Inroduccion y afidofauna de Mallorca. 
Велика цикорієва попелиия (Uroleucon cichorii (Koch, 1855): Sterrnorhyncha: Aphididae) - інвазивний чужсорідний вид фауни Білорусі

Bolletí de la Societat d'Historia Natural de les Balears; 1986,30 , pp 5-17.

52. Buga, S. V.; Stekolshchikov, A. V. Aphids of the tribe Macrosiphini (Insecta: Homoptera: Aphididae) in Belarus. Zoosystematica Rossica; 2012, 21(1), pp 63-96.

53. Tsitsipis, J. A.; Katis, N. I.; Margaritopoulos, J. T.; Lykouressis, D. P.; Avgelis, A. D.; Gargalianou, I.; Zarpas, K. D.; Perdikis, D. Ch.; Papapanayotou, A. A contribution to the aphid fauna of Greece. Bulletin of Insectology; 2007, 60 (1), pp 31-38.

54. Буга, С. В.; Савин, К. А. База данных по тлям Беларуси как инструмент аккумуляции информации о рецедентных видах афидофауны. В: Актуальные проблемы охраны животного мира в Беларуси и сопредельных регионах: материалы науч.-практ. конф., Беларусь, Минск, октябрь 15-18 2018; Кулак А. В. [и др.]. Ред.; Минск, 2018; с 57-60.

55. Holman, J. Host Plant Catalog of Aphids. Palaearctic Region; Springer: Hamburg e.a.; 2009.

56. Рупайс, А. А. Тли (Aphidoidea) Латвии; Зинатне: Рига; 1989.

57. Osiadacz, B.; Wojciechowski, W. Mszyce (Hemiptera: Aphidinea) Ojcowskiego parku narodowego. Struktura i geneza fauny; Bytom, 2008.

58. Чумак, В. О. Попелииі Украӥнських Карпат; Мистецька Лінія: Ужгород; 2004. 